Jurnal Konstruksi Hukum | ISSN: XXXX | E-ISSN: XXXX Vol. 1, No. 2, Oktober 2020, Hal. 379-383| Available online at https://www.ejournal.warmadewa.ac.id/index.php/jukonhum DOI: https://doi.org/10.22225/jkh.1.2.2545.379-383

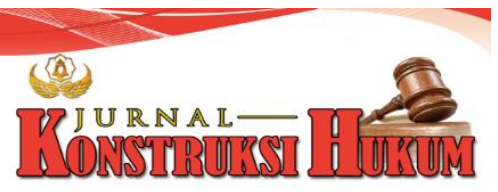

\title{
KEDUDUKAN NOTARIS \& PPAT DALAM PERJANJIAN JUAL BELI TANAH DAN JAMINAN PERLINDUNGAN BAGI PARA PIHAK
}

\author{
I Komang Edy Susanto, Ida Ayu Putu Widia, Ni Gusti Ketut Sri Astiti \\ Fakultas Hukum Universitas Warmadewa, Denpasar-Bali, Indonesia
}

\begin{abstract}
Abstrak
Para notaris pada dasarnya juga merangkap sebagai PPAT (Pejabat Pembuat Akta Tanah) sesudahnya menjalankan uji. Jadi, notaris dalam menjalankan perannya sebagai PPAT berhak untuk membuat akta-akta pemindahan hak atas tanah. Berdasarkan latar belakang tersebut, penelitian ini dilakukan dengan tujuan mendeskripsikan bagaimana kedudukan notaris dan PPAT dalam melakukan mengalihkan hak tanah dan bagaimana perlindungan hukum bagi para pihak yang mengalihkan tanah melalui jual beli. Metode Penelitian yang digunakan dalam penelitian ini adalah metode hukum normatif. Hasil penelitian ini menunjukkan bahwa kedudukan notaris dalam peralihan hak atas tanah sebagai pejabat pembuat akte autentik disebutkan dalam pasal 2 ayat (1) UU No. 2 Tahun 2014 tentang Jabatan Notaris yang menyebutkan notaris ialah pejabat umum yang berwenang untuk membuat akta otentik dan miliki kewenangan lainnya sebagaimana dimaksud di dalam UndangUndang ini atau berdasarkan pada Perundang-Undangan yang lainnya. Kedudukan PPAT pada intinya memiliki tugas untuk melakukan pendaftaran tanah dengan membuat akta sebagai bukti dan sudah melakukan perbuatan hukum tertentu mengenai hak tanah. Perlindungan hukum bagi para pihak yang mengalihkan tanah melalui jual beli tercantum dalam UUD 1945 yakni Pasal 27 ayat (1) yang menyatakan bahwa tiap orang memiliki hak atas pengakuan, penjaminan, perlindungan, dan kepastian hukum yang adil dan perlakuan yang sama dihadapan hukum.
\end{abstract}

Kata Kunci: Jual Beli Tanah; Notaris; Perjanjian; PPAT

\begin{abstract}
Basically, notaries also serve as Land Deed Making Official (hereafter called PPAT) after they carry out a test. Thus, in carrying out their role as PPAT, they are entitled to make deeds of transferring land rights. Based on this background, this research was conducted with the aim of describing how the position of the notary and PPAT in transferring land rights and how legal protection for parties who transfer land through sale and purchase. The research method used in this research was a normative legal method. The results of this study indicated that the position of a notary in the transfer of land rights as an official deed maker is mentioned in article 2 paragraph (1) of Law No. 2/2014 concerning the Position of Notary, which states that a notary is a public official who is authorized to make authentic deeds and has other powers as referred to in this Law or based on other Prevailing Laws. The position of the PPAT in essence has the task of carrying out land registration by making deeds as evidence and having carried out certain legal actions regarding land rights. Legal protection for parties transferring land through sale and purchase is stated in the 1945 Constitution, namely Article 27 paragraph (1) which states that each person has the right to recognition, guarantee, protection, and legal certainty that is just and equal treatment before the law.
\end{abstract}

Keywords: Sale and Purchase of Land; Notary; Agreement; PPAT

\section{PENDAHULUAN}

Di dalam hal keseluruhan tindakan, persetujuan dan ketetapan-ketetapan yang dibuat dibentuk akta otentik, maka para Notarislah yang memiliki hak untuk dapat membuat akta otentik tersebut. Notaris merupakan seseorang yang telah terpilih atau hasil dari pilihan Negara untuk pengambilan suatu sumpah, menjalankan suatu hal dalam dokumen, membuat sah suatu tanda tangan dari seseorang dan melaksanakan suatu tugas atau pekerjaan yang resmi dan telah ditentukan pada bidangnya (Afifah, 
2017). Notaris ialah pejabat umum yang berhak untuk membuatkan akta otentik dan kewenangan lainnya sebagaimana yang telah diartikan dalam Undang-undang tersebut (Hably \& Djajaputra, 2019). Didalam sistem hukum Latin notaris bersifat netral tak memihak dan perlu melakukan pengawasan pada kebutuhan semua pihak.Tugas pokok PPAT ialah untuk menjalankan tindakan pendaftaran tanah dengan membuat akte sebagai bukti telah di jalankannya tindakan hukum tertentu mengenai tanah yang akan didaftarkan.

Notaris berhak untuk membuat Akte otentik mengenai seluruh kegiatan, kesepakatan, dan penetapan yang di haruskan oleh peraturan perundangan. Notaris berhak untuk mengesahkan tandatangan dan menetapkan kepastian tanggal darisurat, di bawah tangan dengan mendaftarkannya didalam buku khusus (Puspa \& Winarno, 2016). Pada dasarnya apabila ada dua pihak atau lebih yang ingin melaksanakan perjanjian dalam bentuk jual beli, sewa menyewa, dan sebagaimana mestinya para pihak yang ingin melakukan suatu memiliki keterkaitan hukum itu pada awalnya akan mencari seorang notaris, dimana dalam hal ini notaris memiliki fungsi dan peranan sebagai penengah didalam pembuatan perjanjian. Setelah ditandatangani oleh para pihak yang terkait maka perjanjian itu dapat dikatakan sudah disepakati oleh para pihak, jadi perjanjian itu akan jadi suatu akta yang selanjutnya wewenang dan tugas dari seorang Pejabat Pembuat Akta Tanah (PPAT). (Paramarta et al., 2017). Posisi seorang Notaris bagi suatu fungsionaris di tengah masyarakat sampai saat ini masih diminati, Seorang Notaris biasanya juga disebut seorang pejabat tempat seseorang bisa mendapatkan nasehat (Haris, 2017).

PPAT punya tugas pokok melakukan pendaftarkan tanah dengan menbuatkan akte sebagai bukti sudah di lakukanya tindakan hukum tertentu tentang tanah. Tugas PPAT punyai kewenangan untuk membuat akta otentik tentang tanah. Dalam kepustakaan istilah power dan auTahunority. Power sebagai kekuasaan dan autahunority diartikan sebagai wewenang. Ada juga kata paksaan yang menujukan pada kekuatan fisik. Ketiga istilah yakni kekuasaan, wewenang dan kekuatan fisik saling terkait satu dengan lainnya. Keterkaitannya itu ialah didalam kekuasaan berisi wewenang, kekuasaan berdasarkan pada aturan hukum, dan didalam menjalankan kekuasaan dan wewenang memerlukan kekuatan dari orang yang memiliki kekuasaan dan wewenang. Seorang notaris memiliki kewenangan untuk membuat suatu akta otentik berdasarkan Undang- undang (Arief et al., 2019). PPAT ialah pejabat umum memiliki hak atau kewenangan yakni punya kekuasaan agar melaksanakan tindakan hukum. Contohnya membuat akta yang terkait dengan tindakan hukum mengenai tanah berdasarkan aturan perundang-undangan, hak yang dijalankan oleh penjabat pembuat buat akta tanah didalam membuat akta dikatakan sah, apabila berdasarkankepada aturan perundang-undangan

Ada beberapa penelitian terdahulu yang melakukan penelitian yang relevan dengan penelitian ini yaitu penelitiannya mengungkapkan bahwa Lemahnya perlindungan hukum ada pada para pihak, karena akta tersebut dibuat atas kesepakatan para pihak, kemudian notaris memformulasikan ke dalam suatu akta yang telah disepakati bersama (Kusuma Putra, 2018). Selanjutnya penelitianya mengkaji tentang akta pengikatan jual beli tanah sebelum dibuatnya akta pejabat pembuat akta tanah (Cipta dkk., 2020). Penelitian ini dilakukan dengan tujuan mendeskripsikan bagaimana kedudukan notaris dan PPAT dalam melakukan pengalihan hak tanah dan bagaimana perlindungan hukum bagi para pihak yang mengalihkan tanah melalui jual beli.

\section{METODE PENELITIAN}

Tipe penelitian yang dipergunakan didalam penulisan jurnal ini ialah penelitian hukum normatif dengan pendekatan perundang-undangan dan pendekatan konseptual berupa legislasi dan regulasi yang terbentuk oleh Lembaga Negara atau Pejabat yang berwenang dalam mengikat seluruh umumdan pendekatan konseptual kepda pandanganyang berkembang didalam ilmu hukum dalam penyelesaian berita hukum yang ada dalam penelitian ini. Teknik pengumpulan bahan hukum yakni dengan studi kepustakaan yang bersumber dari bahan-bahan hukum primer dan bahan hukum sekunder, bahan hukum yang digunakan yaitu berupa peraturan perundang-undangan terkait serta bahan hukum sekunder yang digunakan yaitu berupa doktrin-doktrin, literatur, ataupun buku para ahli yang berkaitan dengan permasalahan yang diteliti. Penelitian hukum merupakan suatu kegiatan ilmiah, yang didasarkan pada metode, sistemmatika dan pemikiran tertentu yang bertujuan untuk mempelajari sesuatu atau beberapa gejala hukum tertentu (Soekanto, 1984). 


\section{HASIL DAN PEMBAHASAN}

\section{Kedudukan Notaris dan PPAT dalam Melakukan Pengalihan Hak Tanah}

Sebagian besar dari notaris ialah pejabat pembuat akta tanah di mana tidak dapat mempengaruhi kekuatan hukum akta yang dibuat oleh seorang notaris yang bukan pejabat pembuat akta tanah (PPAT) maupun notaris yang merupakan pejabat pembuat akta tanah selama masa pembuatan suatu akta diwajibkan untk melengkapi syarat-syarat akta otentik yang ditentukan oleh undang-undang. Sebelum berlakunya UUPA, pengalihan tanah didasari:

1. KUHPerdata

2. OOS 1834 No 27

3. Hukum adat.

Kedudukan Notaris didalam masyarakat sangatlah penting karena berperan fungsionaris hingga sekarang dirasakan masih sangat dihormati. Notaris biasanya dianggap menjadi tempat seseorang untuk memperolehnya nasihat. Semua yang ditulis serta ditetapkannya ialah benar, pasal 1 Peraturan Jabatan Notaris, Notaris ialah membuat akta otentik. Akta otentik itu menurut ketentuan didalam Kitab Undangundang Hukum Perdata, memberikan pihak yang membuatnya untuk pembuktian yang kuat. Notaris diberi hak menciptakan alat bukti yang kuat.

Para Notaris umumnya dapat mempunyai jabatan ganda dimana menjadi seorang Pejabat Pembuat Akta Tanah setelah melewati uji khusus. Maka kedudukannya PPAT berhak pula membuat untuk akta pemindahan hak atas tanah. Tugas poko dari seorang PPAT yitu dalam melakukan pendaftaran tanah dengan cara membuat akte sebagai alat bukti sudah melakukantindakan hukum tertentu tentangtanah. PPAT memiliki kewenangan didalam pembuatan akte otentik mengenai tanah. Didalam kepustakaan didapatkan istilah power dan authority. Power sebagai kekuasaan, authority diartikan sebagai wewenang. Istilah kekuasaan, wewenang dan kekuatan fisik saling terkait. Terkaitnya itu ialah didalam kekuasaan berisi wewenang, kekuasaan didasari pada aturan hukum, agar menjalankan kekuasaan dan wewenang perlu kekuatan fisik dari orang yang punya kekuasaan serta wewenang (Luthan, 2000).

Aturan perundangan yang berisi hak atau kewenenangan pembuat akta tanah dalam membuat akta yang berkaitan dengan tindakan hukum tentang tanah yaitu:

a. Undang-undang No. 4 Tahun 1996 mengenai Hak Tanggungaan Ketanahan bersertanya benda yang Berkaitan dengan Tanah

b. PP No. 4 Tahun 1988 mengenai Rumah Susun

c. PP No. 40 Tahun 1996 tentang Hak Guna Usaha, Bangunan, dan Hak Pakai atas Tanah

d. PP No. 24 Tahun 1997 mengenai Pendaftaran tanah

e. PP Nomor 37 Tahunn 1998 tentang Jabatan PPAT

Notaris diangkat oleh pemerintah untuk melayani publik dalam pembagian hukum untuk melaksanakan salah satu tugas Negara (Erwinsyahbana \& Melinda, 2018). Seseorang notaris diberikan kekuasaan oleh Undang-Undanguntuk membuat akta yang memiliki nilai bukti yang mutlak dan khusus. Notaris juga bertugasuntuk membuat akta otentik dan memiliki wilayah kerja diatur didalam pasal 18 ayat (1) dan undang-undang Nomor 30 Tahun 2004 tentang Jabatan Notaris yang menyatakan bahwa Notaris mempunyai tempat kedudukan didaerah atau kota dan Notaris memiliki seluruh wilayah provinsi dari tempat kedudukannya

Notaris juga harus mempunyai kedudukan kantor yang diatur dalam pasal 19 ayat (1) dan (2) yaitu: (a) Notaris harus memiliki hanya satu kantor ditempat kedudukannya

(b) Notaris tidak berhak secara teratur didalam pelaksanaan tugas jabatannya diluar dari tempat diamana diberkedudukan

Didalam sistem hukum latinnotaris sifatnya netral tak memilih dan perlu mengawasi kebutuhan dari seluruh pihak, PPAT memiliki tugas pokok untuk menjalankan tindakan pendaftaran tanah dengan dibuatkanya akte sebagai bukti sudah menjalankan tindakan hukum tertentu mengenai tanah yang akan didaftarkan. Menurut hukum adat jual beli tanah dimasukan ke hukum benda, khusus hukum benda tetap atau hukum tanah hal ini karena:

a. Jual beli tanah menurut hukum adat tidak sebagai suatu perjanjian jual beli

b. Jual beli menurut hukum adat tak timbulnya tugas dan kewajiban. Hanya ada memindahkan hak dan kewajiban atas tanah. Maka bila pembeli pada awalnya memberikan harga tanah setengah dan tidak melakukan pembayaran sisanya maka penjual tidak bisa menaksa atas terjadinya jual beli tanah tersebut. 
Jual beli yang sudah di lakukan berdasarkan cara yang telah diatur oleh peraturan yang berlaku tersebutdalam Peraturan Pemerintah No. 24 Tahun1997 menjadi jual beli itu sah. Dalam UUPA tidak ada penjelasan tentang apa yang dimaksud dengan jual beli, tapi meskipun itu teringat bahwa hukum argraria itu didasari pada hukum adat tanah, bahwa sistem dan asas yang digunakan dalam hukum tanah (UUPA) ialah sistem dan asas-asas hukum tanah adat. Oleh sebab itu pengertian jual beli tanah menurut UUPA harus diartikan sebagai tindakan hukum yang menyerahan hak milik oleh penjual kepada pembeli dan pada saat yang sama juga memberikan harga kepada penjual, jual beli yang mengakibatkanberubahnya hak tanah dari penjual kepada pembeli itu masuk kedalam hukum agraria atau hukum tanah.

Menurut Luthan (2000), secara yuridis peralihan hak tanah bisa dilakukan dengan beberapa proses, antara lain:

1. Jual beli

2. Hibah

3. Tukar menukar

4. Pemisahan dan pembagian harta warisan

5. Penyerahan hibah wasiat

6. Hipotik

7. Credit verband.

Seorang PPAT puyai kewenangan buat akta otentik mengenai semua perbuatan hukum, khusus hanya berwenang membuat akte mengenai tindakan hukum yang disebut secara khusus dalam penunjukannya. Jual beli tanah ialah sebuah perjanjian yang mana pihak yang memiliki tanah yang disebut penjual, melakukan perjanjian dan mengikat dirinya untuk memberikan haknya atas tanah yang bersangkutan kepada pihak lain yang disebut pembeli. Sedangkan pihak pembeli berjanji dan mengikatkan diri untuk membayar harga yang telah disetujui.

\section{Perlindungan Hukum bagi Para Pihak yang Mengalihkan Tanah melalui Jual Beli.}

Jika para pihak yang melakukan peralihah haktanah mendapatkan jaminan atas peralihan hak atas tanah dapat melalui dengan mendaftarkan tanah. Daftar tanah bermaksud untuk terjamin kepastian hukum hak tanah. jaminan hukum hak tanah, diliat didalamPasal 19 ayat (1) UUPA jo3 huruf (a) PP No. 24 Tahun 1997 yang bertujuan dari daftar tanah ialah agar diberikepastian dan perlindungan hukum bagipemilik hak tanah.

Hukum memiliki arti mengenaipengayoman perlindungan hukum ialah untuk memberikan orang sekitar perasaan nyaman dan aman, agar merasakan semua. Teori ini diartikan juga bahwa perlindungan hukum ialah bersifat menjaga subjek hukum dari hal-hal yang bersifatmerusak, yang dilakukan oleh subjek hukum lainnya. Hukum juga menjaga kepentingan seseorang dalam mengalokasikan kekuasaan agar berbuatsesuai kebutuhannya tersebut. Pengalokasian kekuasaan yang di lakukan dengan cara terukur, dalam artianditentukan oleh keluasan dan kedalamannya (Tedjosaputro). Kekuasaan itu yang disebut hak, tetapi tidak di setiap kekuasaan didalam masyarakat biasa disebut sebagai hak, melainkan hanya kekuasaan tertentu yang menjadi alasan melekat hak itu pada seseorang.

\section{SIMPULAN DAN SARAN \\ Simpulan}

Berdasarkan hasil analaisis data dapat disimpulkan bahwa Kedudukan Notaris di dalam peralihan hak atas tanah sebagai pejabat pembuat akte autentik disebutkan dalam pasal 2 ayat (1) Uu No. 2 Tahun 2014 tentang jabatan notaris yang menyebutkan notaris ialah pejabat umum yang berwenang untuk membuat akte otentik, miliki kewenangan lainnya sebagaimana dimaksud didalam Undang-undang ini atau berdasarkan pada perundang-undangan yang lainnya. Selanjutnya jika pihak yang melakukan peralihah hak atas tanah ingin mendapatkan jaminan dan perlindungan atas peralihan hak atas tanah yang dilakukandengan cara jual beli tercantum dalam UUD 1945 yakni Pasal 27 Ayat (1) yang mengatur bahwa tiap orang memiliki hak atas pengakuan, penjaminan, perlindungan, dan kepastian hukum yang adil dan prilaku yang sama di hadapan hukum.

\section{Saran}

Adapun yang bisa disarankan oleh peneliti yaitu pemerintah dalam mensosialisasikan mengenai kedudukan seorang notaris \& PPAT (Pejabat Pembuat Akta Tanah) dalam perjanjian jual beli tanah dan 
jaminan bagi para pihak yang melakukan perbuatan hukum itu. Pemerintah harus memberikan penjelasan mengenai makna dan tujuan peran notaris dan PPAT kepada masyarakat, dan demi kelancaran sebuah proses perjanjian yang dilakukan oleh para pihak, notaris sebaiknya menjelaskan kepada masyarakat ujuan dan maksud dari peran notaris \& PPAT dalam perjanjian jual beli tanah.

\section{DAFTAR PUSTAKA}

Afifah, K. (2017). Tanggung Jawab dan Perlindungan Hukum bagi Notaris secara Perdata terhadap Akta yang Dibuatnya. Lex Renaissance, 1(2), 147-161.

Arief, A. N. R., Akub, S., \& Muchtar, S. (2019). Persetujuan Majelis Kehormatan Notaris Wilayah dalam Pengambilan Minuta Akta dalam Proses Peradilan. Al-Adalah: Jurnal Hukum Dan Politik Islam, 4(1), 52 81.

Cipta, R. A., Ngadino, \& Prabandari, A. P. (2020). Akta Pengikatan Jual Beli Tanah Sebelum Dibuatnya Akta Pejabat Pembuat Akta Tanah. Notarius, 13(2), 890-905.

Erwinsyahbana, T., \& Melinda. (2018). Kewenangan dan Tanggung Jawab Notaris Pengganti setelah Pelaksanaan Tugas dan Jabatan Berakhir. Lentera Hukum, 5(2), 305-321.

Hably, R. U., \& Djajaputra, G. (2019). Kewenangan Notaris dalam Hal Membuat Akta Partij. Jurnal Hukum Adigama, 2(2), 482.

Haris, M. (2017). Kewenangan Notaris sebagai Pejabat Lelang Kelas II dalam Memberikan Penyuluhan Hukum atas Akta Risalah Lelang yang dibuatnya. Jurnal Ilmu Hukum Dan Pemikiran, 17(1), 53-63.

Kusuma Putra, I. C. (2018). Perlindungan Hukum Notaris Terhadap Perjanjian Perikatan Jual Beli yang Diikuti dengan Adanya Pengakuan Hutang. Jurnal Lex Renaissance, 3(2), 377-390.

Luthan, S. (2000). Dialektika Hukum dan Kekuasaan. Jurnal Hukum IUS QUIA IUSTUM, 7(14), 83-100.

Paramarta, I. W., Widhiyanti, H. N., \& Endah, S. N. (2017). Pertanggungjawaban Notaris Berkenaan dengan Kebenaran Substansi Akta Otentik. Rechtidee, 12(2), 267-285.

Puspa, W. T., \& Winarno, D. W. (2016). Tanggungjawab Notaris terhadap Kebenaran Akta di Bawah Tangan yang Dilegalisasi oleh Notaris. Jurnal Repertorium, 3(2), 154-163.

Soekanto, S. (1984). PengantarPenelitianHukum. UI Press. 